\title{
PENGARUH SIMULASI BENCANA TERHADAP PENINGKATAN KESIAPSIAGAAN MAHASISWA PERAWAT DALAM PENANGGULANGAN BENCANA DIUNIVERSITAS MUHAMMADIYAH PRINGSEWU
}

\section{THEEFFECT OF DISASTERSIMULATION ON INCREASINGSTUDENTNURSEPREPAREDNESS OFDISASTERMANAGEMENT IN UNIVERSITAS MUHAMMADIYAH PRINGSEWU}

\author{
Tiara $^{1}$, Pira Prahmawati ${ }^{2}$ \\ ${ }^{1,2}$ Universitas Muhammadiyah Pringsewu \\ Email :tiara@umpri.ac.id
}

\begin{abstract}
World Disaster 2007, reported that the incidence of disasters had increased by $60 \%$ in 2007 , besides that the number of deaths caused by natural disasters increased from 600,000 to more than 1.2 million people or an increase of 17\% (Klyman, Kouppari \& Mukheir, 2007).

The position of Indonesia's territory which is on the equator and in the form of an archipelago creates a high potential for various types of disasters. One of the disasters is an earthquake. The aim of the studi is To know The Effect of Earthquake Disaster Simulation on Increasing Preparedness of Nursing Students at Muhammadiyah Pringsewu University in 2019. The research design is quasi-experimental. Student population are Seventh semester nursing students are 50 students. Sample of the stduy are 25 respondents in the intervention group and 25 respondents in the control group. The results of disaster training research have effectiveness in increasing students' knowledge of disaster management. The modification of disaster management and occupational health safety training is easier for respondents to understand, so that it is effective in changing the knowledge and attitudes of respondents

Keywords: knowledge, disaster management.
\end{abstract}

\begin{abstract}
Abstrak
World Disaster Report2007, melaporkan bahwa kejadian bencana mengalami peningkatan sebanyak $60 \%$ pada tahunn 2007, selain itu jumlah kematian yang diakibatkan oleh bencana alam meningkat dari 600.000 menjadi lebih dari 1.2 juta jiwa atau menagalami peningkatan $17 \%$ ( Klyman, Kouppari \& Mukheir, 2007).

Posisi wilayah Indonesia yang berada di garis Katulistiwa dan berbentuk Kepulauan menimbulkan potensi tinggi terjadinya berbagai jenis bencan Salah satu bencana adalah gempa bumi.Tujuan untuk mengetahui Pengaruh Simulasi Bencana gempa bumi Terhadap Peningkatan Kesiapsiagaan Mahasiswa Perawat Di UNIVERSITAS MUHAMMADIYAH Pringsewu Tahun 2019. Design penelitian quasi eksperimen. Populasi mahasiswa Mahasiswa perawat semester VII sebanyk 50 mahasiswa. Sample 25 responden pada kelompok intervensi dan 25 responden pada kelompok kontrol. Hasil penelitian pelatihan bencana memiliki efektifitas dalam meningkatkan pengetahuan mahasiswa terhadap penanggulangan bencana. Modifikasi pelatihan manajemen bencana dan keselamatan kesehatan kerja lebih mudah dipahami oleh responden, sehingga efektif merubah pengetahuan dan sikap responden.
\end{abstract}

Kata kunci : pengetahuan, penanggulangan bencana. 
Vol 10 No 2 Juli 2021 | Page 127-132

\section{PENDAHULUAN}

Bencana adalah peristiwa atau rangkaian peristiwa yang mengancam dan mengganggu kehidupan dan penghidupan masyarakat. World Disaster Report2007, melaporkan bahwa kejadian bencana mengalami peningkatan sebanyak $60 \%$ pada tahunn 2007 , selain itu jumlah kematian yang diakibatkan oleh bencana alam meningkat dari 600.000 menjadi lebih dari 1.2 juta jiwa atau menagalami peningkatan 17 \%( Klyman, Kouppari \& Mukheir, 2007). Posisi wilayah Indonesia yang berada di garis Katulistiwa dan berbentuk Kepulauan menimbulkan potensi tinggi terjadinya berbagai jenis bencana.Menurut BNBP, Dalam menghadapi ancaman bencana, kesiapsiagaan menjadi kunci keselamatan. Kesiapsiagaan merupakan serangkaian kegiatan yang dilakukan untuk mengantisipasi bencana melalui pengorganisasian serta melalui langkah yang tepat guna dan berdaya guna. Kegiatan belajar mengajar harus memperhatikan bagaimana pencapaian target interaksi antara siswa dengan kondisi bencana sebagai fokus kualitas pendidikan dan penerapan metode pembelajaran yang tepat untuk membangun profesionalitas dan berpikir kritis.Langkah yang strategis dapat dilakukan untuk meningkatkan kesiapsiagaan perawat adalah dengan memberikan pelatihan atau simulasi tentang penanggulangan bencana. kegiatan pendidikan dan pelatihan kebencanaan di sekolah menjadi strategi efektif, dinamis, dan berkesinambungan dalam upaya penyebarluasan pendidikan kebencanaan (BNBP, 2012 dalam Nurdin, 2018).

Sebagai tenaga kesehatan terbesar Perawat juga harus mengetahui bagaimana kesiapsiagaan bencana diterapkan sehingga bisa meminimalisir risiko bencana dan memperbesar keberhasilan penanganan korban bencana. Kegiatan dari kesiapsiagaan bencana adalah membentuk suatu bagian yang tak terpisahkan dalam sistem nasional yang bertanggung jawab untuk mengembangkan perencanaan dan program pengelolaan bencana yang meliputi: pencegahan, mitigasi, kesiapsiagaan, respon, rehabilitasi atau rekontruksi (Fauziah, 2006, dalam Husna 2012).ICN dan WHO (2009) telah mengembangkan kompetensi keperawatan bencana yang diharapkan dapat dipelajari mahasiswa guna mempersiapkan mahasiswa keperawatan untuk turut andil dalam kegiatan tanggap darurat maupun recovery paska bencana. selama ini mata kuliah keperawatan bencana telah masuk dalam kurikulum mata ajar di prodi SI keperawatan, namun sejauh ini mahasiswa hanya mendapatkan teori dan belum pernah diadakan simulasi bencana alam.

Tujuan dari penelitian ini adalah untuk mengetahui Pengaruh Simulasi Bencana gempa bumi Terhadap Peningkatan Kesiapsiagaan Mahasiswa Perawat Di Universitas Muhammadiyah Pringsewu Tahun 2019.

\section{METODE}

Desain penelitian adalah Quasy Eksperiment, tempat penelitian diUniversitas Muhammadiyah. populasiMahasiswa perawat semester VII di Universitas Muhammadiyah Pringsewu Tahun 2019 sebanyak 50 Mahasiswa. Sampel sebanyak 25 responden pada kelompok intervensi dan 25 responden pada kelompok control. Instrumen penelitian ini menggunakan SOP simulasi bencana dan kuesioner terkait kesiapsiaggan perawat dalam penanggulangan bencana. peneliti memberikan kuesioner berupa sejumlah pertanyaan tentang kesiapsiagaan siswa dalam menghadapi bencana gempa bumi sebelum (pre-test) maupun sesudah (post-test) pelatihan penanggulangan bencana. 
Vol 10 No 2 Juli 2021 | Page 127-132

HASIL

Tabel 1. Karakteristik Jenis Kelamin Responden Penelitian

\begin{tabular}{ccc}
\hline Jenis Kelamin & Frekuensi & Presentase \\
\hline Laki-laki & 15 & $30 \%$ \\
\hline Perempuan & 35 & $70 \%$ \\
\hline Total & 50 & $100 \%$
\end{tabular}

Berdasarkan tabel1 sebagian besar responden berjenis kelamin perempuan yaitusebanyak 35 $(70 \%)$ responden.

Table 2. Distribusi Frekwensi Kategori Pengetahuan pada kelompok kontrol Pelatihan

\begin{tabular}{ccc}
\hline Kategori & Frekuensi & Presentase \\
\hline Baik & 8 & $32 \%$ \\
\hline Cukup baik & 7 & $28 \%$ \\
\hline Kurang baik & 10 & $40 \%$ \\
\hline Total & 25 & $100 \%$ \\
\hline
\end{tabular}

Berdasarkan tabel 2. sebagian besar responden pada kelompok control memiliki pengetahuan kurang baik yaitu sebesar $10(32 \%)$ responden.

Tabel. 3 Distribusi Frekwensi Kategori Pengetahuan Responden Pada kelompok intervensi.

\begin{tabular}{ccc}
\hline Kategori & Frekuensi & Presentase \\
\hline Baik & 15 & $60 \%$ \\
\hline Cukup baik & 6 & $24 \%$ \\
\hline Kurang baik & 4 & $16 \%$ \\
\hline Total & 25 & $100 \%$
\end{tabular}

Berdasarkan table 3 sebagian besar responden pada kelompok Intervensi memiliki pengetahuan baik baik yaitu sebesar $15(60 \%)$ responden

\section{PEMBAHASAN}

Pelatihan manajeman bencana dan keselamatan kesehatan memberika pengaruh terhadap respons persepsi. Pelatihan merupakan kegiatan jangka pendek yang dilakukan secara sistematis sebagai proses belajar untuk mencapai peningkatan pengetahuan, sikap, tindakan dan ketrampilan tertentu.

Berdasarkan hasil penelitian diatas menunjukan bahwa pelatihan bencana memiliki efektifitas dalam meningkatkan pengetahuan mahasiswa terhadap penanggulangan bencana. Berdasarkan hasil presentasi mahasiswa yang mengikiti pelatian memiliki $\mathrm{p}$ pengetahuan baik yaitu sebanyak 15 (60\%) mahasiswa. Hal ini sejalan dengan teori dari Menurut BNPB (2012) kegiatan pendidikan dan pelatihan kebencanaan di sekolah menjadi strategi efektif, dinamis, dan berkesinambungan dalam upaya penyebarluasan pendidikan kebencanaan. Sejalan juga dengan penelitian yang dilakukan oleh Utami, 2018 hasil penelitian nya menunjukan 


\section{Vol 10 No 2 Juli 2021 | Page 127-132}

Kesiapsiagaan siswa setelah diberikan pelatihan penanggulangan bencana terjadi kenaikan pada kesiapsiagaan tingkat sedang $(60,0 \%)$ menjadi kesiapsiagaan tingkat tinggi sebanyak $(46,7 \%)$, dan penurunan pada kesiapsiagaan tingkat rendah sebanyak $(20,0 \%)$. Hal ini membuktikan bahwa setelah mendapatkan pelatihan penanggulangan bencana, terjadi peningkatan tingkat kesiapsiagaan siswa dalam menghadapi bencana gempa bumi (Nurudin, 2015)

Beberapa penelitian sebelumnya menjelaskan bahwa pelatihan program pengurangan risiko bencana bertujuan untuk meningkatkan pengetahuan siswa terhadap bencana gempa bumi serta dampak yang ditimbulkannya. Kegiatan pelatihan para siswa juga diajarkan cara-cara mengantisipasi jika terjadinya bencana gempa bumi. Dengan kata lain, siswa secara aktif melakukan simulasi bencana gempa bumi selama proses pelatihan. Dari hasil di atas terlihat bahwa terdapat perbedaan antara nilai rerata hasil tes awal dan tes akhir siswa (Fajrizal; Kahiruddin; Nizam Ismail, 2016). Hasil penelitian ini bertolak belakang dengan penelitian yang dilakukan oleh Widjanarko (2018) berjudul "Pengaruh pendidikan Bencana pada Perilaku Kesiapsiagaan Siswa" menyebutkan bahwa perbedaan skor pre test dan post test siswa setelah pelatihan sangat kecil. Pengetahuan seseorang dipengaruhi oleh cara pandang terhadap lingkungan serta proses belajar yang dilalui sehingga mendapatkan pengetahuan tersebut (Notoatmodjo, 2003). Yang dapat memengaruhi terhadap perilaku kesiapsiagaan bencana. Pendidikan merupakan media terbaik untuk meningkatkan pengetahuan dan pemahaman tentang bencana, suatu komunitas. Pendidikan bencana mudah dimengertim melalui proses pembelajaran. Kesiapan individu terhadap bencana dapat diketahui dengan adanya pengetahuan, keterampilan, dan kemampuan yang diperoleh melalui pembelajaran berdasarkan pengalaman yang diaplikasikan secara nyata saat kondisi darurat. Pendidikan kebencanaan perlu disampaikan kepada mahasiswa di Program studi ilmu geografi Universitas Kanjuruhan Malang, karena mahasiswa merupakan agen of chance yang akan berperan sebagai edukator kesiapan bencana. Mahasiswa siap untuk diterjunkan kepada masyarakat, sehingga diharapkan mampu memberikan intervensi yang tepat pada saat bencana terjadi (Kurniawati, 2016). Peneliti menyimpulkan bahwa Perubahan persepsi sikap bergantung pada penerimaan individu terhadap stimulus yang diberikan. Individu mempunyai kecenderungan besar untuk menentukan, dan informasi akan diterima apabila individu: suka terhadap stimulus, kemudahan untuk mengerti informasi, ada minat dan perhatian, serta kebutuhan terhadap stimulus (sangat memerlukan). Berbeda dengan penelitian sebelumnya, membuktikan bahwa sikap dipengaruhi oleh pengetahuan tetapi tidak menjelaskan bahwa proseperubahan sikap.

\section{SIMPULAN}

Tingkat pengetahuan mahasiswa pada kelompok intervensi memiliki pengetahuan baik yait sebanyak 15 (62\%) responden dibandingkan dengan mahasiswa dengan kelompok kontrol.

\section{SARAN}

Modifikasi pelatihan manajemen bencana dan keselamatan kesehatan kerja lebih mudah dipahami oleh responden, sehingga efektif merubah pengetahuan dan sikap responden. Pemahaman mendorong seseorang untuk membentuk sikap positif yang dapat membentuk perilaku seseorang 


\section{DAFTAR PUSTAKA}

Azka Fathiyatir Rizqillah Disaster Preparedness, 2012 : Survey Study Pada Mahasiswa Keperawatan Universitas Harapan Bangsa Purwokerto

BNPB., 2012. Pedoman Penyelenggaraan Latihan Kesiapsiagaan Penanggulangan Bencana: Jakarta.BNBP, 2007

Chapman K, Arbon P. Are nurses ready? Disaster preparedness in the acute setting. Australas Emerg Nurs J 2008; 1:135-44. doi: 10.1016/j.aenj.2008.04.002.

Dunlop AL, Logue KM, Isakov AP, 2014 The engagement of academic institutions in communitydisaster response: A comparative analysis. Public Health Rep 2014; 129:87-95.

Galliara M, Prabhawalkar A, 2012. Disaster management and role of academic institutions. Soc Work Chron ; 1:1-29

Husna, Cut 2012 Faktor-Faktor Yang Mempengaruhi Kesiapsiagaan Bencana Di Rsudza Banda Aceh Influencing Factors On Disaster Preparedness In Rsudza Banda Aceh file:///C:/Users/User/Downloads/1578-2967-1-SM\%20(1).pdf

International Council of Nurses, 2017. Disaster Nursing : Geneva, Switzerland

ISDR. (2004). Terminology: Basic terms of disaster risk reduction. Available from International Strategy for Disaster Reduction: http://www.unisdr.org/eng/library/lib-terminologyeng\%20home.htm,

ICN. (2006). Nurses and disaster preparedness. Geneva: International Council of Nurses.

ICN. (2001). Nurses and disaster preparedness: A position statement. Geneva: International Council of Nurses.

Rencana Nasional Penanggulangan Bencana 2015-2019 https://bnpb.go.id/uploads/24/buku-renaspb.pdf

Yamamoto, A., \& Watanabe, T. (2006). Disaster nursing competencies. Japan: University of Hyogo, Graduate School of Nursing.

Yang, Kyeongra, G.R. Woomer, dan J.T. Matthews. (2011). Collaborative learning among undergraduate students in community health nursing. Journal of Nurse Education in Practice

Nursalam. 2012. Pendekatan Praktis Metodologi Riset Keperawatan Cetakan Pertama. Jakarta, Infomedika.

Notoatmodjo, S. 2012. Metodologi Penelitian Kesehatan. Jakarta, PT. Rineka Cipta.

Notoatmodjo, S. 2010. Metodologi Penelitian Kesehatan. Jakarta, PT Rineka Cipta

Nurdin, 2018. Pengaruh Pelatihan Penanggulangan Bencana Gempa Bumi Terhadap Kesiapsiagaan Siswa Kelas Vii Di Smp Negeri 1 Imogiri Bantul Yogyakarta. Journal

The International Classification for Nursing Practice, 2015. https://www.icn.ch/sites/default/files/inlinefiles/ICNP Catalogue Disaster Nursing.pdf

WHO. (2008). Medium-term strategic plan 2009-2013. Available from World HealthOrganization: http://www.who.int/gb/ebwha/pdf_files/AMTSP-PPB/a-mtsp_3en.pdf 
Vol 10 No 2 Juli 2021 | Page 127-132

Warfield, C. (n.d.). The Disaster management cycle. Available from Disaster Mitigation and Management: http://www.gdrc.org/uem/disasters/1-dm_cycle.html 